Research Based Article

\title{
TINGKAT DUKUNGAN ORANG TUA TERHADAP BELAJAR SISWA
}

Juster Donal Sinaga *
Universitas Sanata Dharm

\begin{abstract}
THE LEVEL OF PARENTS SUPPORT TO LEARN CHILDREN. This study aims to describe the level of parents support to learn children. The results of this study serve as the basic design of home visit services as one way to improve the parent support system in learning children. This research is a quantitative research. The subjects of this study were students of grade VIII at SMPN 31 Purworejo which amounted to 31 students. The research data was collected using Parent/Guardian Support Questionnaire to Child Learning and Questionnaire of Child's Opinion on Support of Parent/Guardian developed by the researcher from Ariffin concept (1992) with the number of items of each instrument as much as 40 . Reliability value of instrument were calculated using Cronbach Alpa formula of 0,886 . The data were analyzed by descriptive statistic using mean, mean, average, and standard deviation. Descriptions go through the categorization of normal distribution by category: very high, high, medium, low, and very low. The findings of this study show that $41 \%$ of parents/guardians have support for children's learning in very high category, $45,1 \%$ of high category, and $12,9 \%$ of moderate category. Based on the opinion of the students, there are $45,1 \%$ students who believe that the carrying capacity of the parents/guardian to the learning of the child is in very high category, $45,1 \%$ of the high category, $6,4 \%$ of the medium category, and found $3,2 \%$ of the low category. These findings serve as a basis for providing trajectory to parents to improve parental support systems for child learning.
\end{abstract}

* Corresponding Author: Program Studi Bimbingan dan Konseling, FKIP Universitas Sanata Dharma; Jalan Affandi Tromol Pos 29, Mrican, Catur Tunggal, Depok, Caturtunggal, Kec. Depok, Kabupaten Sleman, Daerah Istimewa Yogyakarta 55002; Email: donalsinaga@usd.ac.id.

Article History: Received: 27-10-2017; Revised: 15-11-2017; Accepted: 04-1-2018

Permalink: http://ijec.ejournal.id/index.php/counseling/article/view/19

How to cite (APA): Sinaga, J. D. (2018). Tingkat dukungan orang tua terhadap belajar siswa. Indonesian Journal of Educational Counseling, 2(1), 43-54

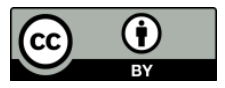

This is an open access article distributed under the terms of the Creative Commons Attribution 4.0 International License, which permits unrestricted use, distribution, and reproduction in any medium, provided the original work is properly cited. @ 2018, Juster Donal Sinaga.

\section{PENDAHULUAN}

Salah satu faktor yang dapat mempengaruhi prestasi belajar siswa adalah peranan dan dukungan serta keterlibatan dari orang tua terhadap belajar siswanya. Salah satu aspek yang mempengaruhi keberhasilan belajar siswa yang 
berkaitan dengan orang tua yakni keterlibatan orang tua dalam pendidikan siswanya. Orang tua memegang tugas penting terhadap perkembangan fisik dan mental siswanya. Tugas orang tua yang paling penting terletak pada tugas edukasi (mendidik). Tugas ini terlihat dari pola asuh yang diterapkan oleh orang tua kepada siswanya.

Orang tua merupakan pendidik yang pertama dan utama dalam membantu mengembangkan potensi siswa-siswanya. Banyak hal yang dapat dilakukan orang tua dalam mendorong anak-anaknya untuk meningkatkan prestasi belajarnya. Partisipasi orang tua terhadap peningkatan prestasi belajar siswa dapat berupa memberikan waktu yang cukup untuk belajar, memenuhi kebutuhannya, memberikan motivasi dalam belajar, dan keterlibatan orang tua dalam belajar siswa-siswanya. Induk peran dan tanggung jawab orang tua antara lain dapat diwujudkan dengan membimbing kelangsungan anak belajar di rumah sesuai dengan program yang telah dipelajari oleh siswa-siswa di sekolah. Membimbing anak belajar di rumah dapat dilakukan dengan mengawasi dan membantu pengaturan tugas sekolah serta menyelesaikan instrumen dan infrastruktur siswa belajar (Umar, 2015).

Membimbing anak belajar di rumah oleh orang tua artinya membantu perkembangan sikap, nilai, kebiasaan dan keterampilan yang mendorong keberhasilan siswa melalui kesediaan orang tua memotivasi anak sehingga berprestasi dalam belajar (Stainback \& Stainback, 1999, p. 30). Orang tua dapat memotivasi anak dengan cara menghargai prestasi anak, memberikan hukuman yang sifatnya mendidik, menyediakan fasilitas belajar yang cukup, dan bersedia melibatkan diri dalam belajar anak. Sejalan dengan pendapat tersebut Martin (2000: 25) mengatakan peran orang tua dalam membimbing anak belajar di rumah yaitu menjadi pendengar aktif, membantu anak menyusun jadwal dan pelaksanaannya, memperhatikan kondisi fisik terutama kesehatan anak, memperhatikan kondisi psikis anak dengan memberikan hadiah maupun peringatan, dapat mengenali dan mengembangkan gaya belajar anak.

Di dalam keterlibatan orang tua terdapat beberapa unsur pendukungnya, yakni perhatian yang cukup, ketersediaan waktu yang berkualitas, kasih sayang yang cukup, serta keterlibatan orang tua dalam belajar siswanya. Keterlibatan orang tua memegang peranan yang sangat penting dalam perkembangan umum siswa, khususnya dalam belajar siswa. Efek dari keterlibatan orang tua dalam belajar siswa salah satunya siswa menjadi sukses dalam pembelajaran di sekolah, karena orang tua mendukung dan terlibat dalam pendidikan siswa.

Dalam penelitian Tolada (2013) menunjukkan bahwa adanya hubungan keterlibatan orang tua dengan prestasi belajar siswa. Penelitian yang sejenis menemukan bahwa terdapat pengaruh yang signifikan keterlibatan orang tua 
terhadap prestasi belajar siswa. Terdapat 37,9\% prestasi belajar siswa dipengaruhi oleh keterlibatan orang tua, sedangkan $62,1 \%$ dipengaruhi oleh faktor lain (Ristiani, 2015). Temuan-temuan tersebut sejalan dengan pernyataan Henderson dan Berla (1994, p. 160) yang mengatakan:

"the most accurate predictor of a student's achievement in school is not income or social status but the extent to which that student's family is able to: Create a home environment that encourages learning Express high (but not unrealistic) expectations for their children's achievement and future careers Become involved in their children's education at school and in the community".

Orang tua dan sekolah merupakan dua unsur yang saling berkaitan dan memiliki keterkaitan yang kuat satu sama lain. Supaya orang tua dan sekolah tidak salah dalam mendidik siswa perlu kerjasama yang baik di antara kedua belah pihak tersebut. Orang tua mendidik siswa di rumah, guru mendidik siswa di di sekolah. Namun dalam kenyataan, orang tua dan sekolah tidak selalu dapat bekerjasama dengan baik dalam rangka mendidik siswa. Salah satu kebiasaan yang lazim terjadi pada oranag siswa adalah kepedulian orang tua meningkat ketika mendekatai masa-masa ujian. Mulai dari orang tua bertanya kepada guru dan siswa tentang pelajaran sampai mengirim siswa ke berbagai privat agar siswa dapat lulus. Tindakan orang tua yang seperti ini jauh dair tindakah preventif. Tindakan yang hampir sama juga dipraktekkan oleh sekolah. Penambahan jam pelajaran, pemberian materi tambahan, tes uji coba dilakukan sekolah menjelan Ujian Nasional. Demikian juga yang terjadi di Sekolah Menengah Pertama Negeri 31 (SMPN 31) Purworejo. Ada beberapa siswa kelas IX yang perlu mendapat perhatian lebih karena nilai akademiknya yang rendah. Tulisan ini bertujuan untuk mendeskripsikan tingkat daya dukung orang tua terhadap belajar anak. Selain dari penilaian orang tua sendiri terhadap dirinya, tingkat daya dukung orang tua juga diperoleh dari pendapat siswa.

Keberhasilan siswa dalam belajar salah satunya ditentukan perilaku belajar siswa yang mandiri. Perilaku belajar dapat diartikan sebagai sebuah aktivitas belajar. Belajar diartikan sebagai perubahan yang secara relatif berlangsung lama pada perilaku yang diperoleh kemudian dari pengalaman-pengalaman (Davidoff, 1998;178). Morgan dkk (Walgito, 2003, p. 166) mengartikan belajar sebagai perubahan yang relatif menetap pada perilaku yang terjadi sebagai akibat dari latihan atau pengalaman. Hal yang muncul dalam definisi ini adalah bahwa perubahan perilaku atau performance itu relatif permanen. Di samping itu juga dikemukakan bahwa perubahan perilaku itu sebagai akibat belajar karena latihan (practice) atau karena pengalaman (experience). Pada pengertian latihan dibutuhkan usaha dari individu yang bersangkutan, sedangkan pada pengertian pengalaman usaha tersebut tidak tentu diperlukan. Ini mengandung arti bahwa dengan pengalaman seseorang atau individu dapat berubah perilakunya, di 
samping perubahan itu dapat disebabkan oleh karena latihan. Dari definisi tersebut dapat dikemukakan bahwa belajar itu merupakan suatu proses adaptasi perilaku yang bersifat progresif. Ini berarti bahwa sebagai akibat dari belajar adanya sifat progresivitas, adanya tendensi ke arah yang lebih sempurna atau lebih baik dari keadaan sebelumnya (Walgito, 2003, p. 166).

Di antara ciri-ciri perubahan khas yang menjadi karakteristik perilaku belajar yang terpenting adalah perubahan itu intensional; perubahan itu positif dan aktif; dan perubahan itu efektif dan fungsional. Belajar merupakan kegiatan mental yang tidak dapat disaksikan dari luar. Apa yang sedang terjadi dalam diri seseorang yang sedang belajar, tidak dapat diketahui secara langsung hanya dengan mengamati orang itu. Bahkan, hasil belajar orang itu dapat langsung kelihatan, tanpa orang itu melakukan sesuatu yang menampakkan kemampuan yang telah diperoleh melalui belajar. Dari uraian di atas, dapat disimpulkan bahwa perilaku belajar adalah suatu aktivitas mental/psikis, yang berlangsung dalam interaksi aktif dengan lingkungan, yang menghasilkan perubahan-perubahan dalam pengetahuan pemahaman, ketrampilan dan nilai sikap.

Salah satu perilaku belajar yang mampu membawa siswa meraih sukses dalam belajarnya adalah kemandirian belajar. Menurut Merriam dan Caffarella (2001), kemandirian (self direction in learning) merupakan proses dimana individu mengambil inisiatif dalam merencanakan, melaksanakan dan mengevaluasi sistem pembelajarannya. Berbeda dengan pendapat Grieve (2003) yang mengatakan bahwa kemandirian belajar adalah atribut personal, kesiapan psikologis seseorang dalam mengontrol sehingga bertanggung jawab dalam proses belajarnya. Ada beberapa faktor yang mempengaruhi kemandirian belajar yaitu sumber sosial artinya orang dewasa yang berada di lingkungan siswa seperti orang tua, anggota keluarga dan guru. Sumber kedua adalah keterampilan yang memberikan kesempatan untuk melatih kemandirian belajar siswa, dengan demikian siswa akan mempunyai kemandirian belajar yang baik jika selalu dimotivasi secara bersama-sama baik oleh guru, orang tua sehingga siswa merasa dirinya memiliki kemampuan lebih untuk mengerjakan tugas sesuai dengan ketrampilan yang ada. Menurut Bandura (1997), salah satu faktor yang mempengaruhi kemandirian belajar adalah faktor lingkungan (kebudayaan, keluarga, sistem pendidikan di sekolah, sistem kehidupan di masyarakat).

Menurut Santrock (2003) keluarga merupakan pilar utama dan pertama dalam membentuk siswa mandiri. Dukungan yang paling besar dalam lingkungan rumah bersumber dari orang tua. Orang tua diharapkan dapat memberikan kesempatan kepada siswa agar dapat mengembangkan kemampuan yang dimilikinya, belajar mengambil inisiatif, mengambil keputusan mengenai apa yang ingin dilakukan dan belajar mempertanggungjawabkan atas segala perbuatannya. 
Apabila siswa diberikan suasana yang penuh perlindungan, penghargaan, kasih sayang dan perhatian orang tua, maka akan jauh dari perasaan iri, cemburu, tersaingi sehingga siswa akan mendorong dan menunjukkan sifat mandiri, mempunyai keberanian untuk melatih dirinya, berinisiatif, bertanggung jawab, serta dapat menyelesaikan masalahnya sendiri, baik dalam bidang akademis maupun non akademis.

Dukungan yang diberikan keluarga akan menjadi kekuatan dan motivasi bagi siswa-siswa untuk belajar (Bakar, 2011). Sehingga siswa akan lebih semangat untuk memperoleh keputusan yang lebih cemerlang untuk masa depannya. Lingkungan keluarga memberikan pengaruh positif terhadap aktifitas belajar siswa artinya apabila dukungan sosial keluarga tersebut harmonis, kondisi ekonomi berkecukupan, perhatian orang tua mempunyai peranan penting terhadap pencapaian prestasi belajar baik dalam hal kedisiplinan, atau problem solving siswa. Tanpa adanya dukungan sosial keluarga permasalahan kemandirian siswa dalam belajar akan sulit diatasi. Dukungan orang tua merupakan sistem dukungan sosial yang terpenting di masa remaja. Dibandingkan dengan sistem dukungan sosial lainnya, dukungan orang tua berhubungan erat dengan kesuksesan akademis remaja, konsep diri, harga diri, percaya diri, motivasi dan kesehatan mental. Keterlibatan orang tua dihubungkan dengan prestasi sekolah, emosional dan penyesuaian diri selama sekolah.

Menurut Hawes \& Jesney (Padavick, 2009), keterlibatan orang tua diartikan sebagai partisipasi orang tua terhadap pendidikan dan pengalaman siswanya. Berdasarkan hal tersebut, dapat disimpulkan keterlibatan orang tua merupakan partisipasi orang tua dalam pendidikan belajar siswa baik di sekolah maupun di tempat lain yang dapat mendukung kemajuan siswa. Keterlibatan orang tua merupakan proses keterlibatan keluarga yang meliputi sikap, nilai-nilai, dan praktik orang tua dalam membesarkan siswa. Hubungan siswa dengan orang tua yang hangat dan responsif, serta partisipasi orang tua dalam aktivitas yang berpusat pada siswa dapat berpengaruh positif terhadap hasil belajar siswa. Keterlibatan orang tua bagi siswa akan mendorong untuk mengembangkan rasa memiliki, menghargai diri sendiri, dan aman. Ketika siswa mempunyai orang tua yang sensitif dan responsif terhadap siswa, siswa akan lebih berkompeten secara sosial dan menunjukkan kemampuan komunikasi yang lebih baik. Rasa hangat, timbal balik interaksi orang tua dengan siswa, dan sedikit tekanan di dalam rumah dapat membuat siswa lebih mudah bersosialisasi dan berkonsentrasi.

Di dalam lingkungan keluarga, orang tualah yang berperan menjadi pendidik yang pertama dan utama bagi siswanya untuk mengembangkan potensinya. Orang tua menjadi pendidik yang pertama, karena orang tua yang pertama kali mendidik siswanya sejak ia dilahirkan. Dikatakan sebagai pendidik utama, karena 
pendidikan yang diberikan orang tuanya bersifat mendasar dan sangat menentukan perkembangan siswa selanjutnya. Keluarga merupakan lingkungan pendidikan yang pertama dan utama. Disebut sebagai lingkungan atau lembaga pendidikan pertama karena sebelum manusia mengenal lembaga pendidikan yang lain, pendidikan inilah yang pertama ada.

Menurut Soelaeman (Shochib, 2010, p. 14), untuk mengamati secara cermat, mendalam, dan menyeluruh upaya orang tua dalam membantu siswa memiliki dan mengembangkan dasar-dasar disiplin dirinya, perlu diarahkan pada empat hal, yaitu: (1) pribadi orang tua yang konkret, (2) pribadi siswa yang konkret, (3) situasi lugas dalam kehidupan keluarga, dan (4) arah tindakan untuk siswa agar memiliki dasar-dasar disiplin diri dan mengembangkannya.

Menurut Ariffin (1992) terdapat empat peran orang tua dalam mendukung prestasi belajar siswa, yaitu: (1) Pengasuh dan pendidik. Orang tua berperan sebagai pendidik sebab dalam pekerjaannya tidak hannya mengajar, tetapi juga melatih ketrampilan siswa, terutama sekali melatih sikap mental siswa. Maka dalam hal ini, orang tua harus dan mampu bertanggung jawab untuk menemukan bakat dan minat siswa, sehingga siswa diasuh dan dididik, baik langsung oleh orang tua atau melalui bantuan orang lain, seperti guru, sesuai dengan bakat dan minat siswa sendiri, sehingga siswa dapat memperoleh prestasi belajar secara lebih optimal; (2) Pembimbing. Bimbingan adalah segala kegiatan yang dilakukan oleh seseorang dalam rangka memberikan bantuan kepada orang lain yang mengalami kesulitan, agar orang tersebut mampu mengatasinya sendiri dengan penuh kesadaran. Maka dalam hal ini, orang tua harus senantiasa memberikan bimbingan secara berkelanjutan. Siswa di sekolah hannya enam jam, dan bertemu dengan gurunya hanya sampai 2 dan 3 jam. Maka prestasi belajar siswa sangat didukung oleh bimbingan belajar yang diberikan orang tua secara berkelanjutan, langsung maupun tidak langsung; (3) Motivator. Orang tua memberikan dorongan tentang pentingnya belajar dengan tujuan dapat meningkatkan prestasi belajar, sehingga siswa benar-benar merasa penting dan membutuhkan apa yang dianjurkan oleh orang tuanya. Orang tua harus mampu menjadi motivator belajar siswa. Hal ini dilakukan antara lain dengan membimbing belajar siswa dengan kasih sayang secara berkelanjutan, serta dengan menciptakan suasana belajar di rumah. Suasana belajar dapat diwujudkan dengan meminimalisir kebiasaan-kebiasaan yang kurang bermanfaat, seperti menonton TV secara terus menerus, maka bagaimana suasana belajar mampu dikondisikan oleh orang tua, maka sejauh itu pula siswa termotivasi untuk belajar; (4) Fasilitator. Dalam belajar-mengajar orang tua menyediakan berbagai fasilitas seperti media, alat peraga, termasuk menentukan berbagai jalan untuk mendapatkan fasilitas tertentu dalam menunjang program belajar siswa. Orang tua sebagai fasilitator turut mempengaruhi tingkat prestasi yang dicapai siswa. 
Bentuk dukungan lain yang tidak kalah pentingnya berkenaan dengan peranan orang tua dalam belajar siswa adalah dengan menyiapkan berbagai fasilitas pembelajaran. Fasilitas ini dimulai dengan biaya pendidikan karena tidak ada pendidikan gratis seratus persen. Fasilitas pendidikan selanjutnya adalah berkenaan dengan penyediaan buku-buku ajar yang dibutuhkan peserta didik, demikian juga dengan fasilitas lainnya, seperti alat-alat tulis, tempat belajar, dan lain-lain.

ACT Department of Education and Training (2015) menjelaskan beberapa strategi potensial mendukung belajar siswa di rumah, yaitu:

“1) Have regular and ongoing ways of finding out what parents need to engage with their child's learning; 2) Include practical literacy and numeracy activities that involve parents in homework; 3) Provide parents with information about where students are up to in their learning, what progress they have made over time and what parents might do to support their child's further learning; 4) Develop kits and resources to help families work with children at home; 5) Provide parent/teacher workshops targeting areas of need or interest such as student resilience, literacy and numeracy; 6) Involve families in setting goals for their children's learning (personalised learning plans); 7) Embed the practice of involving parents in goal setting and career planning discussions with their children; 8) Develop local strategies to support transitions between early childhood education and care, primary school and secondary school, higher education and the workforce"

Orang tua seringkali tidak maksimal menjalankan perannya dalam belajar siswa. Akibat dari tidak berjalannya peran orang tua dalam belajar siswa maka sistem dukungan orang tua terhadap pendidikan siswa menjadi terganggu.

\section{METODE}

Jenis penelitian ini adalah penelitian kuantitatif. Metode yang digunakan dalam penelitian ini adalah survei untuk mendapatkan data lapangan tentang tingkat daya dukung orang tua terhadap belajar anak. Subjek penelitian ini adalah orang tua siswa kelas VIII SMPN 31 Purworejo yang berjumlah 31 orang tua.

Data penelitian dikumpulkan menggunakan instrumen yang dikembangkan oleh peneliti denggan menggunakan konsep Arifin (1992) dengan jumlah item masing-masing instrumen sebanyak 40. Instrumen berupa kuisioner terdiri dari dua jenis: 1) Kuesioner Dukungan Orang Tua terhadap Belajar Anak; dan 2) Kuesioner Pendapat Anak terhadap Dukungan Orang Tua dalam Belajar Anak Kuesioner disusun berbentuk skala.

Skala yang digunakan dalam instrumen penelitian ini mengacu pada prinsipprinsip Skala Likert. Instrument ini merupakan alat untuk mengukur tingkat dukungan orang tua terhadap belajar anak dan tingkap pendapat siswa terhadap dukungan orang tua terhadap belajar anak. Jawaban-jawaban terhadap item tersebut akan menggambarkan tingkat dukungan orang tua terhadap belajar 
anak. Kuesioner Dukungan Orang Tua/Wali terhadap Belajar Anak memiliki lima alternatif jawaban, yaitu Sangat Sering (SS), Sering (S), Jarang (J), KadangKadang (KK), dan Tidak Pernah (STS). Sedangkan Kuesioner Sikap Anak terhadap Dukungan Orang Tua/Wali dalam Belajar Anak memiliki lima aalternatif jawaban, yaitu Sangat Setuju (SS), Setuju (S), Ragu-Ragu (RR), Tidak Setuju (TS), dan Sangat Tidak Setuju (STS). Nilai reliabilitas instrumen yang dihitung menggunakan formula Alpa Cronbach sebesar 0,886.

Data penelitian dianalisis secara statistik deskriptif menggunakan nilai mean, rata, rata, dan standar deviasi. Pendeskripsian melalui kategorisasi distribusi normal dengan kategorisasi: sangat tinggi, tinggi, sedang, rendah, dan sangat rendah.

\section{HASIL DAN PEMBAHASAN}

Berdasarkan data yang terkumpul diperoleh gambaran tingkat daya dukung orang tua/wali terhadap belajar anak seperti pada gambar grafik berikut ini.

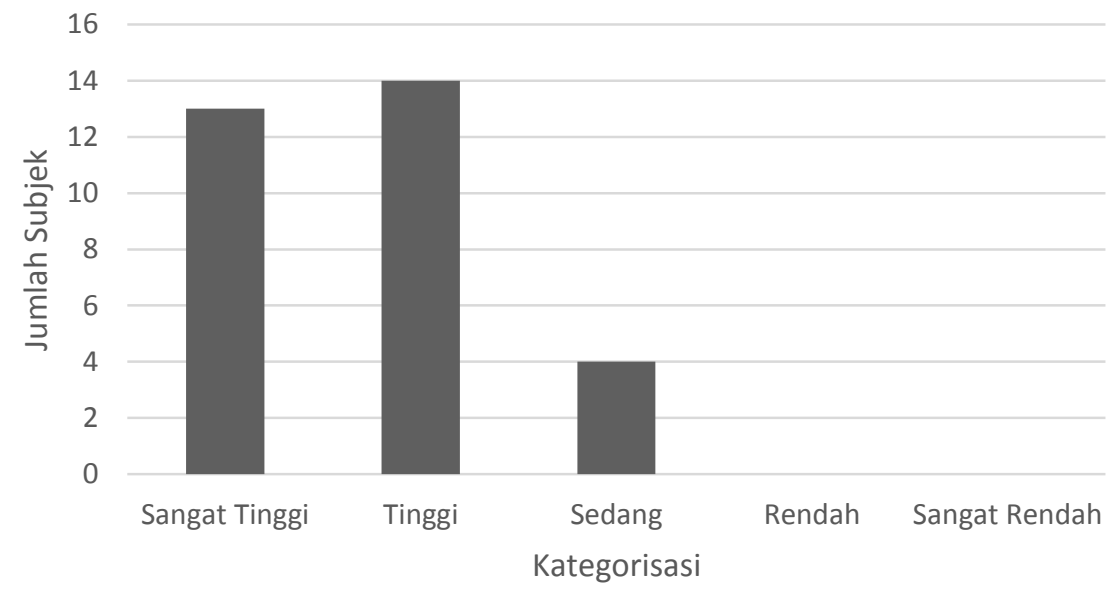

\section{Gambar 1. Grafik Distribusi Kategori Tingkat Daya Dukung Orang Tua/Wali terhadap Belajar Anak}

Berdasarkan grafik pada Gambar 1, tampak bahwa ada 13 (41,9\%) orang tua yang memiliki daya dukung terhadap belajar anak masuk dalam kategori sangat tinggi, $14(45,1 \%)$ orang tua memiliki daya dukung terhadap belajar anak kategori tinggi, dan $4(12,9 \%)$ orang tua memiliki daya dukung terhadap belajar anak masuk dalam kategori sedang, serta tidak ada orang tuan yang masuk kategori rendah dan sangat redah daya dukungnya terhadap belajar anak.

Sedangkan tingkat dukungan orang tua/wali terhadap belajar anak menurut pendapat siswa tanpak dalam gambar grafik berikut ini. 


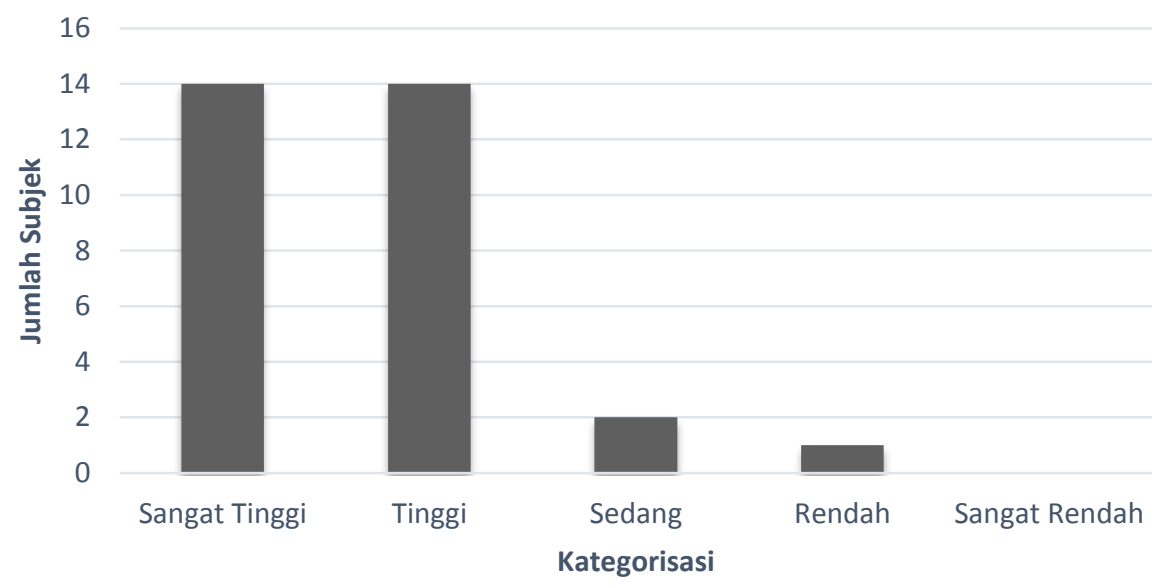

\section{Gambar 2. Grafik Distribusi Kategori Tingkat Daya Dukung Orang Tua/Wali terhadap Belajar Anak Berdasarkan Pendapat Siswa}

Berdasarkan grafik pada Gambar 2 ditemukan 14 (45,1\%) siswa yang berpendapat bahwa daya dukungun orang tua atau wali terhadap belajar mereka masuk kategori sangat tinggi. Sejumlah yang sama siswa berpendapat bahwa orang tua atau wali mereka memiliki daya dukung kategori tinggi. Ditemukan 2 $(6,4 \%)$ siswa berpendapat bahwa daya dukung orang tua mereka terhadap belajar masuk kategori sedang, dan 1 siswa $(3,2 \%)$ berpendapat bahwa daya dukung orang tua mereka masuk kategori rendah, serta tidak ada siswa yang berpendapat daya dukung orang tua mereka masuk kategori sangat rendah.

Dari data orang tua ditemukan 4 orang tua yang perolehan sekor daya dukung terhadap belajar anak masuk kategori sedang. Sedangkan dari data siswa ditemukan 3 siswa yang memandang orang tua atau wali mereka kurang memiliki daya dukungan dalam belajar. Setelah dianalisis, data penilaian orang tua terhadap daya dukung mereka yang berada pada kategori sedang dan data pendapat siswa yang berada pada kategori kurang setuju dan tidak setuju merujuk pada orang tua yang sama. Empat orang tua tersebut akan dijadikan sebagai subjek yang mendapatkan layan home visit untuk meningkatkan sistem dukungan orang tua terhadap belajar anak.

Berdasarkan temuan penelitian yang mengungkapkan bahwa sebagian besar orang tua memiliki daya dukung sangat tinggi dan tinggi terhadap belajar anak, membuktikan bahwa sebagian besar orang tua siswa memberikan perhatian terhadap pendidikan anaknya. Hal ini membuktikan apa yang dikatakan Santrock (2003) bahwa keluarga merupakan pilar utama dan pertama dalam membentuk siswa mandiri. Dukungan yang paling besar dalam lingkungan rumah bersumber dari orang tua. Juga sejalan dengan yang dikatakan Hawes \& Jesney 
(Padavick, 2009) bahwa keterlibatan orang tua diartikan sebagai partisipasi orang tua terhadap pendidikan dan pengalaman siswanya. Keterlibatan orang tua merupakan partisipasi orang tua dalam pendidikan belajar siswa baik di sekolah maupun di tempat lain yang dapat mendukung kemajuan siswa.

Keterlibatan orang tua merupakan proses keterlibatan keluarga yang meliputi sikap, nilai-nilai, dan praktik orang tua dalam membesarkan siswa. Hubungan siswa dengan orang tua yang hangat dan responsif, serta partisipasi orang tua dalam aktivitas yang berpusat pada siswa dapat berpengaruh positif terhadap hasil belajar siswa. Hal ini terbukti dari beberapa butir kuesioner yang skor rata-ratanya tinggi. Misalnya item nomor 29: "Seberapa sering Anda bersikap tidak peduli akan kebutuhan fasilitas belajar anak Anda di rumah?" dengan skor rata-rata 4,84 dari skala 1-5. Artinya, sebagian besar orang tua mendukung belajar anak dengan menyediakan fasilitas belajar. Penyediaan fasilitas belajar termasuk dalam dukungan instrumental. Bentuk dukungan instrumental orang tua misalnya penyediaan saranan dan prasarana bagi pencapaian prestasi atau penguasaan kompetensi (Lestari, 2012).

Demikian juga item nomor 38 yang berbunyi: "Seberapa sering Anda memberikan nasehat-nasehat bijak tentang manfaat belajar untuk masa depan kepada anak Anda?". Item ini memperoleh skor rata-rata sebesar 4,58. Temuan ini dapat diartikan bahwa orang tua mendukung belajar anak dengan memberikan nasehat-nasehat dan motivasi. Dukungan yang sejenis ini tergolong dalam dukungan emosi, yaitu dukungan yang mengarah pada aspek emosi dalam relasi orang tua dan anak, yang mencakup perilaku-perilaku yang secara fisik atau verbal menunjukkan afeksi atau dorongan dan komunikasi positif (Lestari, 2012). Temuan-temuan tersebut membuktikan bahwa dukungan orang tua terhadap belajar anak mampu memotivasi anak untuk meraih prestasi dalam belajar. Seperti yang diungkapkan Bakar (211), dukungan yang diberikan keluarga akan menjadi kekuatan dan motivasi bagi siswa-siswa untuk belajar, sehingga siswa akan lebih semangat untuk memperoleh keputusan yang lebih cemerlang untuk masa depannya.

Namun demikian, temuan penelitian yang mengungkap 4 orang tua yang memiliki daya dukung rendah terhadap belajar anak menunjukkan bahwa diperlukannya dukungan sekolah untuk membantu orang tua membangun sistem dukungan terhadap belajar siswa. Berdasarkan analisis identifikasi butir item yang perolehan skor rata-ratanya rendah ditemukan 8 item. Dari delapan item tersebut terungkap bahwa bahwa rendahnya kehadiran orang tua secara konkrit dalam belajar anak. Seperti yang diungkapkan Soelaeman (Shochib, 2010: 14), untuk mengamati secara cermat, mendalam, dan menyeluruh upaya orang tua dalam membantu siswa memiliki dan mengembangkan dasar-dasar disiplin dirinya, perlu 
diarahkan pada empat hal, yaitu: (1) pribadi orang tua yang konkret (2) pribadi siswa yang konkret, (3) situasi lugas dalam kehidupan keluarga, dan (4) arah tindakan untuk siswa agar memiliki dasar-dasar disiplin diri dan mengembangkannya. Dari konsep tersebut dapat diartikan bahwa rendahnya dukungan orang tua terhadap belajar karena ketidakhadiran orang tua secara konkrit. Hal ini dapat dibuktikan dari delapan item yang teridentifikasi tersebut. Misalnya item nomor 19 dengan skor rata-rata 2, 58 berbunyi: "Seberapa sering Anda berbicara dengan anak Anda tentang kemalasan-kemalasanya dalam belajar?" Dari pernyataan tersebut dapat dipahami bahwa orang tua kurang hadir secara konkrit dalam bentuk komunikasi.

\section{SIMPULAN}

Berdasarkan temuan atau hasil penelitian dan pembahasan di atas, dapat disimpulkan beberapa hal sebagai berikut:

Tingkat dukungan orang tua terhadap belajar anak sebagian besar berada dalam kategori sangat tinggi dan tinggi, hanya sebagian kecil yang berada pada kategori sedang dan rendah. Tingkat dukungan orang tua terhadap belajar anak menurut pendapat anak juga sebagian besar berada pada kategori sangat tinggi dan tinggi, dan hanya sebagian kecil berada pada kategori sedang dan rendah.

Empat orang tua yang daya dukung terhadap belajar anak baik menurut persepsi orang tua maupun menurut pendapat anak direkomendasi mendapatkan treatmen melalui layanan home visit. Rendahnya daya dukung orang tua terhadap belajar anak dikarenakan ketidakhadiran orang tua secara konkrit baik dalam bentuk emosi maupun dalam bentuk instrumental. Hal ini ditemukan dari analisis item instrumen penelitian.

\section{REFERENSI}

ACT Department of Education and Training. (2015). Progressing Parental Engagement School Fact Sheet: Supporting children's learning at home. Retrieved July 19, 2017, from website http://www.det.act.gov.au/_data/assets/pdf_file/0006/807441/150897Supporting-childrens-learning-at-home_2.pdf.

Arifin. (1992). pokok-pokok pemikiran tentang bimbingan dan penyuluhan agama. Jakarta: Bulan Bintang.

Bakar, A., Kamaruddin, I. M., \& Yang, M. T. (2006). Hubungan antara minat pelajar dan sikap ibu bapa dengan prestasi matematik terbaik pelajar. Journal of Educational Psychology and Counseling, 1, 25-43. 
Bandura, A. (1997). Self efficacy. New York: WH Freeman \& Company.

Davidoff, L. L. (1998). Psikologi Suatu Pengantar (edisi ke-2). Jilid 2. Jakarta: Erlangga.

Grieve, K. (2003). Supporting learning, supporting change: A research project on self-management and self-direction. Toronto: Ontario Literacy Coalition.

Lestari, S. (2012). Psikologi keluarga, penanaman nilai dan penanganan konflik dalam keluarga. Jakarta: Prenadamedia.

Merriam, S. B., \& Caffarella, R.S. (2001). Learning in adulthood: A comprehensive guide. San Francisco: Jossey-Bass Publishers.

Padavick, J. F. (2009). Parental involvement with learning and increased student achievement. (Unpublished doctoral's dissertation) Walden University, Minneapolis, Minnesota, USA.

Ristiani, E. P. (2015). Pengaruh keterlibatan orangtua dalam belajar terhadap prestasi belajar siswa kelas $v$ sekolah dasar negeri se-daerah binaan III Kecamatan Petarukan Kabupaten Pemalang. (Unpublished undergraduate's thesis) Universitas Negeri Semarang, Semarang, Indonesia.

Santrock, J. W. (2003). Psikologi pendidikan. Jakarta: Kencana Prenada Media Group

Shochib, M. (2010). Pola asuh orang tua (Dalam membantu anak mengembangkan disiplin diri sebagai pribadi yang berkarakter). Jakarta: Rineka Cipta.

Stainback, W., \& Stainback, S. (1999). Bagaimana membantu anak anda berhasil di sekolah. (Y. M. Setiyanta, Trans.). Yogyakarta: Kanisius. (How to help your child succeed in school. Original work published 1988).

Tolada, T. (2012). Hubungan keterlibatan orang tua dengan prestasi belajar anak usia sekolah di SDIT Permata Hati, Banjarnegara. (Unpublished undergraduate's thesis) Universitas Indonesia, Depok, Indonesia.

Umar, M. (2015). Peranan orang tua dalam peningkatan prestasi belajar anak. JURNAL EDUKASI: Jurnal Bimbingan Konseling, 1(1), 20-28.

Walgito, B. (2003). Psikologi sosial. Yogyakarta: Andi Yogyakarta. 